\title{
THE SEMANTICS OF BIRD DENOMINATIONS IN THE MARI LANGUAGE
}

\author{
Kristina Yuzieva \\ University of Tartu
}

\begin{abstract}
This paper presents an analysis of the semantics of bird denominations in Mari: an attempt is made to define the factors, or features, motivating bird denominations. Analysis is based on a set of words of inner origin that are part of the corpus of bird names compiled by the author. The results show that the ornithonomy of the Mari language, created over centuries, constitutes a well-shaped system. It reflects a variety of features associated with the appearance, way of life of the birds, sounds they produce, etc. Many bird terms reflect features of appearance. It is interesting to note that the names of birds not seen for some reason may relate to the characteristics of the birds' voices. In some cases, terms are based on a combination of features. In dialects, different names for same birds may occur, as observed in the sources.
\end{abstract}

Keywords: bird terminology, semantics, ornithonym, denomination features, motivating factors, Mari

\section{Introduction}

The vocabulary of a language with time undergoes changes conditioned by the development of a society. The semantic group uniting bird names is a relatively open structure; terms can disappear or become replaced by new ones. Research on bird terminology presents interest from both theoretical and practical points of view. The results of this analysis of bird names in Mari are relevant to research on the terminology of the language and can be useful for the description of bird denominations in other Uralic languages.

The theme of bird terminology has been treated by many authors; in some works, bird names used in Finno-Ugric languages have been analyzed (for example: Mäger 1967, Sokolov 
1973, Jenő 1984, Sivula 1989, Bogár 2007, etc.). Research has been done on the semantic, etymological, linguistic-geographical and other aspects of the subject. The ornithology of Mari has been described by V. N. Vasil'jev (1984); nearly 300 terms have been analyzed by the researcher, mainly from the point of view of etymology.

The present article provides a semantic analysis of bird names in Mari, among which there are over 300 terms not treated before; the aim of the analysis is defining the features that underlie bird denominations.

\section{Methodology of research}

In current onomathology, thematic groups are distinguished in accordance with the principles of denomination, in other words, onomasiological models, or generalized aspects and features (like colour, action, origin, etc.) underlying the naming of homogeneous groups of objects (Gol'ev 1981).

Motivating factors in some cases are clear, as the semantics of the words is transparent. There are, however, bird names, the etymology of which is undefined; research is required to disclose it. The semantics and the structure of the lexical units are considered to be the fundamental aspects of denominations (Varina 1976: 242-243); for the purposes of description, sets of underlying features are established.

In this respect, it should be noted that bird terms defined in the existing dictionaries mostly in Russian in some cases do not display the feature conveyed by the original word. The following examples can be considered. The feature "food" (parda $\check{s}$ 'fish') is not reflected in the definition of the term pardaštumna ${ }^{l}$ ("ptica semejstva sovinyx"; Slovar' marijskogo jazyka V: 37), Russ. 'moxnonogij syč', Lat. 'Aegolius funereus', Engl. 'Teng-

1 Transliteration in the case of Mari and Russian ornithonyms is in accordance with the code presented on the internet site «The Journal of Estonian and Finno-Ugric Linguistics», the symbols added here are: $\ddot{a}=\ddot{a}, H=\eta \mathrm{g}$ $=\ddot{\mathrm{o}}, \ddot{\mathrm{y}}=\ddot{\mathrm{u}}$. 
malm's Owl'2. Likewise, the definition of the term šörlogo, šörlüštyšö ("ptica semejstva kozodoev"; Slovar' marijskogo jazyka IX: 271), Russ. 'kozodoj', Lat. 'Caprimulgus europaeus', Eng. 'Nightjar' does not convey the feature "voice" (šör 'milk', logo 'thrush'); the word šörlüštyšö is onomatopoetic, it denotes the sounds produced during milking.

The feature "the time of arrival" (šokšy 'warmth') is not denoted in the definition of the term occurring in the Hill variety of Mari: šokšygek (gek 'bird') ("ptica semejstva djatlovyx"; Slovar' marijskogo jazyka IX: 197), Russ. 'vertišejka', Lat. 'Junx torquilla', Engl. 'Wryneck'. As seen from the examples, such generalized definitions contain no indication of a concrete feature reflected in the Mari terms.

In other cases denomination features may be hidden, not distinct in the semantics of a word. For example, the feature "a bird's voice compared with an animal's voice" is not reflected in the semantics of the term jumyntaga literally: «blessed + ram»), Russ. 'bekas', Lat. 'Gallinago gallinago', Engl. 'Snipe'.

It has been noted by some authors (see in Mäger 1967: 190) that relatively similar principles of bird denominations occurring in different languages eventually condition similarity in the semantics of the denominations themselves, cp. for example, the terms: Lat. 'Botaurus stellaris', Engl. 'Bittern': Est. vee-, soo-, merehärg 'water, marsh, sea bull', Hung. nadibika 'reed bull', Germ. Wasserochs 'water bull', Russ. vodjanoj byk 'water bull', Mar. vüdüškyž 'water bull', удм. vиоš 'water bull', etc. This circumstance has to be considered in the analysis of bird names that have been created through reproduction or analogy occurring due to cultural contacts between peoples.

There is a certain amount of similarity between the systems of denomination used in different languages; this is explained by the fact that ornithonyms convey information related to the natural biological features of birds. There is an opinion that the study of the principles and features of denomination cannot be reduced to a linguistic analysis, as they are directly

2 For English bird names, Lars Svensson «Collins bird guide» (2009) has been used as reference. 
conditioned by extra-linguistic factors. The motivating factors of denomination and the classification of the features of denominations are directly connected with the characteristics of the realia (see: Gol'ev 1972).

It has been suggested that within each thematic group of bird names, distinction should be primarily made between the major groups of features (names relating to the appearance of the birds - group A, way of life - group B, bird sounds - group C). Within the major groups of features, sub-groups of specific features that are directly related to the characteristics of a bird are further distinguished (Gol'ev 1972).

Classification based on both direct and indirect ways of denomination has been used to describe ornithonyms in the Tatar language (Safina 2006: 62). A total of 25 groups have been identified in the vocabulary of bird terms in Tatar, which shows that bird denominations constitute a complex system. It can be mentioned that indirect denomination is not salient in Mari.

Classification suggested in a research dealing with the ornithology of Northern Russia (Lysova 2002) has been based on two principles of denomination, by which features possessed by objects and features related to objects are distinguished.

In the present work, methodology used in the previous research of bird terminology in different languages is taken into account. The set of terms used in the analysis allows differentiating two groups of motivating features; within these, several sub-groups of features are specified.

Observations in the research were made of the terms used in Meadow Mari, Eastern Mari, and Hill Mari. Materials for analysis were selected from dictionaries and other sources, documents, as well as interviews with informants (mainly held in localities of the Republic of Bashkortostan). 


\section{Analysis of bird terminology}

\subsection{Features possessed by an object as the basis of bird denominations}

Among the features possessed by the objects those of the voice, size, appearance (or a detail of it), conduct, way of life of birds can be identified as motivating factors.

\subsubsection{Bird denominations based on the fea- ture "voice"}

It has been noted in literature that of all the features used for bird denominations the bird's voice in its different manifestations is the most frequent. The author of research on bird terminology in Saami writes: "In all languages, one of the most important etymological types of bird names is onomatopoeia, as one of the most characteristic features of a bird is exactly its sound" (Bogár 2009: 9). An analysis of Finnish bird names based on onomatopoeia has shown that in the book "Linnut värikuvina" ("Coloured pictures of birds"), half of the 274 names signify bird sounds (Marttila 2010: 3).

The Eastern Mari names träk, Russ. 'čajka', Lat. 'Chroicocephalus ridibundus', Engl. 'Black-headed Gull', vyle-vyle Russ. 'sviristel', Lat. 'Bombycilla garrulus', Engl. 'Waxwing' are onomatopoetic words. Sopsyrenge // čopčyrange, Russ. 'sorokoputžulan', Lat. 'Lanius collurio', Engl. 'Red-backed Shrike' denote a bird producing the sounds sor-sor-sor-sor (Üpymarij 1926: 192).

An ornythonym can also convey a similarity between the sounds produced by two different birds or by a bird and an animal. For example, in saršüšpyk literally: "golden oriole», Russ. 'ivolga', Lat. 'Oreolus oreolus', Engl. 'Golden Oriole', the singing of the golden oriole is compared with the singing of the nightingale, which looks different; in jumyntaga literally: "blessed lamb”, Russ. 'bekas', Lat. 'Gallinago gallinago', Engl. 'Snipe', the sounds produced by the bird, when it flies, are compared to those of a lamb. In another case, apšatkajyk literally: 
"bird-blacksmith", Russ. 'penočka-ten'kovka', Lat. 'Phylloscopus collybita', Engl. 'Chiffchaff', the term is based on a similarity between the sounds produced by the bird and the sounding of the beats produced by a blacksmith.

Bird names can specify the character of sounds: some birds, for instance, can cry, whistle, laugh loudly, etc. See the Eastern Mari term šüškyšö jükčö literally: "a whistling swan", Russ. 'lebed'-šipun', Lat. 'Cygnus olor', Engl. 'Mute Swan'.

Fairly frequently ornithonyms formed as compound words are onomatopoetic. It is interesting to note that the names of many species of birds with a prominent voice sound similar in Finno-Ugric (as well as other) languages. Such onomatopoetic names being linguistic parallels have common source - sounds produced by a given bird.

The name of the cuckoo bird can serve as an example: Lat. 'Cuculus canorus', Engl. 'Cuckoo' in several related languag$e^{3}$ : Finn. kaki, Est. kägu, Hung. kakuk, Mar. kuku, Udm. kiky. Similar parallels can be observed in the case of the word crow: Lat. 'Corvus', Engl. 'Crow'; it can be noticed that the terms can be split into two subgroups ${ }^{4}$, in accordance with the elements "kar-kor" and "var" occurring in the words: Finn. varis, Est. vares, Hung. varju, Md. varaka, Mar. korak, Udm. kuaka. In the Finno-Ugric languages the name of black grouse has a combination of consonants, $t r$, in its base form, which corresponds to the bird's voice (Mäger 1967: 63).

It can be assumed that bird names based on onomatopoeia go back to the time when hunting was the main resource for getting food. Precise reproduction of the birds' voices helped the hunters to get prey in abundance. In a talk, hunters referring to a bird can have used a word imitating its voice. With time, such

3 Annu Marttila states that in a study of the names of the cuckoo and of the words that describe the voices of the cuckoo, a sample of terms from $74 \%$ of the languages of "Eurasia" was found to contain $88 \%$ of onomatopoetic words (Marttila 2010: 3-4).

4 According to the study of Annu Marttila in 130 languages (92\%) out of 141 different languages observed, the bird's voice was reflected in its name. In Africa: khware, kurak, kaa, gaga ja gaak, in Eurasia kaakaa, kaag, kwag, korb, krkavets, etc. (Marttila 2010: 4). 
indications of birds used in speech became transformed; however, the form has phonetically remained similar to the original one, due to the continuity of the relationship between the people and the birds; that is, the possibility of hearing the birds' voices ("ku-ku", "kar-kar") in everyday life has been lasting.

\subsubsection{Bird denominations based on the feature "size"}

The feature "size" is usually used to distinguish certain species of birds. In Mari, differently, for example, from Russian, there is a number of ornithonyms with the components small and big, which constitute pairs. Examples of terms with the components izi 'small', and kugu 'big' are: iziviškyr, Russ. 'malaja poganka', Lat. 'Podiceps ruficollis', Engl. 'Black-necked Grebe', and kugyviškyr, Russ. 'bol'šaja poganka', Lat. 'Podiceps cristatus', Engl. 'Great Crested Grebe'; izitumna, Russ. 'vorob'inyj syč', Lat. 'Glaucidium passerinum', Engl. 'Pygmy Owl'; kugytumna, Russ. 'seraja nejasyt', Lat. 'Strix aluco', Engl. 'Tawny Owl'; izilogo, Russ. 'belobrovnik', Lat. 'Turdus iliacus', Engl. 'Redwing'; kugylogo, Russ. 'derjaba', Lat. 'Turdus viscivorus', Engl. 'Mistle Thrush'; izivaraš, Russ. 'kobčik', Lat. 'Falco vespertinus', Engl. 'Red-footed Falcon'; kugyvaraš, Russ. 'koršun', Lat. 'Milvus', Engl. 'Kite'.

Size as a feature has also been used with reference to the size of another bird of the same species. In the examples that follow, the second component refers to species: Hill Mari izigek literally: "small bird", Russ. 'obyknovennaja ovsjanka', Lat. 'Emberiza citrinella', Engl. 'Yellowhammer'; izijumyntaga Russ. 'garšnep', Lat. 'Lymnocryptes minimus', Engl. 'Jack Snipe'; izikupšül'ö, Russ. 'kukša', Lat. 'Perisoreus infaustus', Engl. 'Siberian Jay'; izičečkem, Russ. 'malaja muxolovka', Lat. 'Ficedula parva', Engl. 'Red-breasted Flycatcher'.

Parts of a bird's body can be big, small, short, long, thick, thin, etc., for example: kužyner literally: "long beak", Russ. 'bol'šoj veretennik', Lat. 'Limosa limosa', Engl. 'Black-tailed Godwit'; kugyner literally: «big beak», Russ. 'obyknovennyj 
zimorodok', Lat. 'Alcedo atthis', Engl. 'Kingfisher'; küžgyner literally: «thick beak», Russ. 'obyknovennyj dubonos', Lat. 'Coccothraustes coccothraustes', Engl. 'Hawfinch'; küčykpoč literally: «short tail», Russ. 'krapivnica', Lat. 'Troglodytes troglodytes', Engl. 'Wren'; kužypočkisa literally: «long-tailed tit», Russ. 'opolovnik', Lat. 'Aegithalos caudatus', Engl. 'Long-tailed Tit'.

\subsubsection{Bird denominations based on the feature "colour"}

The chromatic characteristics, or colour, of ornithonyms are important descriptive features used for distinguishing and denominating birds. Some ornithonyms denoting the colour of the birds' feathers are formed according to the model "colour + the name of the species". For example, oštumna literally: «white owl», Russ. 'belaja (poljarnaja) sova', Lat. 'Bubo scandiacus', Engl. 'Snowy Owl', čaltumna literally: «grey owl», Russ. 'dlinnoxvostaja nejasyt', Lat. 'Strix uralensis', Engl. 'Ural Owl', šemšište literally: «black woodpecker », Russ. 'želna', Lat. 'Dryocopus martius', Engl. 'Black Woodpecker'; užaršište literally: «green woodpecker», Russ. 'zelenyj djatel', Lat. 'Picus viridis', Engl. 'Green Woodpecker', užargorak literally: "green crow", Russ. 'rakša', Lat. 'Coracias garrulous', Engl. 'Roller', sarkuku literally: "yellow cuckoo", Russ. 'gluxaja kukuška', Lat. 'Cuculus optatus', Engl. 'Oriental Cuckoo'.

Colour as a feature underlying ornithonyms in Mari can also be used with respect to a certain part of the body of a bird, as seen from the following examples: joškaroy literally: "red breast", Russ. 'snegir', Lat. 'Purrhula purrhula', Engl. 'Bullfinch', joškarvuj literally: «red head», Russ. 'krasnogolovyj nyrok', Lat. 'Aythya ferina', Engl. 'Pochard'; ošpoč literally: "white tail”, Russ. 'orlan-beloxvost', Lat. 'Haliaetus albicilla', Eng. 'White-tailed Eagle'; ošsayga literally: "white forehead”, Russ. 'kamyšnica', Lat. 'Gallinula chloropus', Engl. 'Moorhen'; ošpočvaraš literally: "hawk-white tail", Russ. 'lugovoj lun', Lat. 'Circus pygargus', Engl. 'Montagu's Harrier', šemšüj literally: “white neck”, Russ. 'xoxlataja černet', Lat. 'Aythya fuligula', Engl. 'Tufted Duck'. 


\subsubsection{Bird denominations based on the feature "form"}

One of the underlying features of bird denominations is form, which can refer to definite parts of a bird's body. Among the denominations of this type are words like važykner, važykumša literally: «crooked beak, mouth»; Russ. 'klest-elovik', Lat. 'Loxia curvirostra', Engl. 'Common Crossbill', vüržner literally: "awl + beak”, Russ. 'piščuxa', Lat. 'Certhia familiaris', Engl. 'Treecreeper'.

A term can indicate a particular detail of a bird's appearance: pylyšantumna literally: «long-eared owl », Russ. 'filin', Lat. 'Bubo bubo', Engl. 'Eagle Owl', pylyšanvi kyr literally: «pylyšan 'long-eared' + viškyr 'name of species'», Russ. 'malaja poganka', Lat. 'Podiceps ruficollis', Engl. 'Black-necked Grebe'.

As a basis for denomination, comparison with the form of some object can be used. See the following examples: savaner literally: "plait + beak" Russ. 'bol’šoj kronšnep', Lat. 'Numenius arquata', Engl. 'Curlew'; vüržvoč literally: "awl + beak”, Russ. 'šiloxvost', Lat. 'Anas acuta', Engl. 'Pintail', mygyl'šü literally: "mygyl' 'ringlet on the back of the head of a woman' $+\check{s} \ddot{u}<5 \check{s} \ddot{j}$ "neck", Russ. 'seraja caplja', Lat. 'Ardea cinerea', Engl. 'Grey Heron'; šarvoč literally: "šar 'hair, mainly of the tail of a horse' + poč 'tail'”, Russ. 'šiloxvost', Lat. 'Anas acuta', Engl. 'Pintail'.

\subsection{Denominations based on factors related to the birds' way of life}

Factors related to the birds' way of life used as the basis of denominations include food, distribution in nature, associations with natural and religious beliefs. 


\subsubsection{Bird denominations based on the feature "food"}

In this type of denominations the following terms can be found: koljagajyk literally: "kolja 'mouse' + kajyk 'bird", Russ. 'pustel'ga', Lat. 'Falco tinnunculus', Engl. 'Kestrel', èyyžgajyk literally: "èyyž 'raspberries' + gajyk < kajyk 'bird”,, Russ. 'malinovka', Lat. 'Erithacus rubecula', Engl. 'Robin', sügygajyk literally: "sügö 'beetle' + kajyk 'bird",, Russ. 'sinica-moskovka', Lat. 'Periparus ater', Engl. 'Coal Tit'.

The ornithological vocabulary also contains names that have been formed according to the scheme "an object of food + participle kočšo "feeding on", for example: kolkočšo literally: "feeding on fish", Russ. 'obyknovennyj zimorodok', Lat. 'Alcedo atthis', Engl. 'Kingfisher', lyvygočšo literally: "feeding on butterflies", Russ. 'obyknovennyj kozodoj', Lat. 'Caprimulgus europaeus', Engl. 'Nightjar', karmygočšo literally: 'feeding on flies", Russ. 'malaja muxolovka', Lat. 'Ficedula parva', Engl. 'Red-breasted Flycatcher', etc.

In some bird names not only an item of food but also the manner of feeding is indicated; for example: užarčüngyšö literally: "pecking greenery" (čüngaš 'to peck'), Russ. 'vertišejka', Lat. 'Junx torquilla', Engl. 'Wryneck'.

It should be mentioned that bird terms can also denote the capacity of a bird to consume large amounts of food. For example, in Mari the terms for the grey heron are kugylogar (kugu 'big' + logar 'throat') and podlogar ( pod 'pot'+ logar 'throat').

\subsubsection{Bird denominations based on the feature "distribution"}

With respect to the dwelling, nesting, or meeting places, birds are differentiated as those living in water, land, and marsh. Ornithonyms can contain different components that serve as indications of location or flora. See the examples: čodyračečkem (čodyra 'forest'), Russ. 'slavka-černogolovka', Lat. 'Sylvia atricapilla', Engl. 'Blackcap'; olykčečkem (olyk 'meadow'), Russ. 
'lugovoj čekan', Lat. 'Saxicola rubetra', Engl. 'Whinchat'; kuptumna (kup 'marsh'), Russ. 'bolotnaja sova', Lat. 'Asio flammeus', Engl. 'Short-eared Owl'; sergajyk (ser 'shore'), Russ. 'beregovaja lastočka', Lat. 'Riparia riparia', Engl. 'Sand Martin'; nužgajyk (nuž 'stinging nettle'), Russ. 'krapivnik', Lat. 'Troglodytes troglodytes', Engl. 'Wren'; kožgisa (kož 'Picea, spruce'), Russ. 'opolovnik (dlinnoxvostaja sinica)', Lat. 'Aegithalos caudatus', Engl. 'Long-tailed Tit', etc.

Some of the bird names contain information about food as well as the place, where the birds can be mostly seen; in such cases it is difficult to define the primary feature underlying the term. See, for example: šoptyrčečkem literally: "šoptyr 'currants' + čečkem 'garden warbler'”, Russ. 'slavka sadovaja', Lat. 'Sylvia borin', Engl. 'Garden Warbler', čiegajyk literally: "čie 'cherry' + gajyk < kajyk 'bird”,', Russ. 'penočka-vesnička', Lat. 'Phylloscopus trochilus', Engl. 'Willow Warbler', lokamagajyk literally: «lokama 'wild rose' + gajyk 'bird', Russ. 'žulan', Lat. 'Lanius collurio', Engl. 'Red-backed Shrike'.

\subsubsection{Bird denominations based on the feature "activity, arrival or leaving period"}

The following terms illustrate the category of ornithonyms signifying a period of time: jüdvara literally: "night hawk", Russ. 'kozodoj', Lat. 'Caprimulgus europaeus', Engl. 'Nightjar', pör ökajyk literally: "hoar-frost bird" (the denomination indicates the period of arrival, i.e. during a cold period when there is hoar-frost), Russ. 'snegir', Lat. 'Purrhula purrhula', Engl. 'Bullfinch'. As a name for bullfinch, the word ör , an abbreviated form of öršökajyk (pöršökajyk), Hill Mari örš 'hoarfrost' (Vasil'jev 1983: 50) is used. In Eastern Mari, the ornithonym üdymgajyk, Russ. 'lugovoj čekan', Lat. 'Saxicola rubetra', Engl. 'Whinchat' denotes the time of the bird's arrival, that is, when field works begin. 


\subsubsection{Bird denominations associated with popular beliefs, omens, weather prediction}

In Mari bird denominations of this type are not numerous. Several terms provided with examples showing their use are given below. See: jüstygajyk literally: "jüštö 'cold' + kajyk 'bird”, omen: "Jüstygajyk magyra gyn, jüštö sajynak lieš” “Зяблик голосит - крепкие морозы будут" (Kitikov 1989: 56) 'If the chaffinch cries - a period of frost will come', Russ. 'zjablik', Lat. 'Fringila coelebs', Engl. 'Chaffinch'; ayagajyk literally: "aya 'field, plot' + gajyk 'bird"" connected with the beginning of field works: "Ayagajyk muro šergyltmek, kalyk aya pašaš lekteš”. - “Запела вертишейка - настала пора полевых paбот" (Kitikov 1989: 156) 'If the wryneck started singing - it is time to start field works', Russ. 'vertišejka', Lat. 'Junx torquilla', Engl. 'Wryneck'. There is an omen, according to which it is most sinful to shoot a swan'; jumynkajyk literally: "jumyn 'divine' + kajyk 'bird”', Russ. 'lebed'-klikun', Lat. 'Cygnus Cygnus', Engl. 'Whooper Swan'.

\section{Conclusions}

The semantic analysis of bird denominations shows that ornithonymy has been created over centuries. The range of motivating factors established in the analysis allows stating that ornithonyms used in Mari constitute a well-defined system. Different groups of motivating factors have been used for bird denominations in the language; some of them prove to be more frequent than others. Appearance displayed in many forms has been identified as the factor most frequently occurring in the bird denominations of Mari. Colour, with reference to an object or parts of its body, details of the birds' appearance, size constitute a set of features underlying bird denominations. Voice is often used as a motivating factor, especially in cases, when the birds for some reason cannot be seen. For some terms, several features may be found to be reflected. 
A name of a bird can be transferred to another bird; similarity between two birds displayed in their appearance, voice, or behaviour is in such cases an important factor.

The rich nomenclature of ornithonyms used in the language is a sign showing the people's subtle perception of nature and their creative mind expressed over time.

\section{Address:}

Kristina Yuzieva

University of Tartu

Jakobi 2

51004 Tartu, Estonia

E-mail: kristina.yuzieva@gmail.com,kristina.yuzieva@ut.ee

\section{References}

Bogár, Edit G. (2009) The Lappish (Saami) bird names (a linguistic analysis). Egyetemi doctori (PhD) értekezés tézisei. Debrecen: University of Debrecen, Doctoral School for Linguistics.

Gol'ev, Nikolaj Danilovič (1972) "O principax nominacii i metode ix issledovanija".In Materialy nauč. konferencii, posvjaščennoj 50-letiju obrazovanija SSSR: Ligvistika. Teoretičeskie voprosy russkogo jazyka i ego govorov 5, 94-99. Available online at $<$ http://lingvo.asu. $\mathrm{ru} / \mathrm{golev} / \mathrm{articles} / \mathrm{z} 66 . \mathrm{html}>$. Accessed on 14.03.2012.

Gol'ev, Nikolaj Danilovič (1981) "O nekotoryx obščix osobennostjax principov nominacii v dialektnoj leksike flory i fauny". In Russkie govory Sibiri, 17-28. Available online at $<\mathrm{http}$ ://ingvo.asu.ru/golev/articles/ z08.html>. Accessed on 14.03.2012.

Kiss, Jenő (1984) Magyar madárnevek: (az Európai madarak elnevezései). Budapest: Akadémiai Kiadó.

Kitikov, Aleksandr Efimovič (1989) Marij kalyk pale-vlak. Joškar-Ola: Marijskoe knižnoe izdatel'stvo.

Lysova, Elena Vladimirovna (2002) Ornitonimija Russkogo Severa: aftoref. dis. ... kand. filol. nauk. Ekaterinburg: Izd-vo UrGU.

Marttila, Annu (2010) "Leksikaalinen ikonisuus ja sen esiintyminen linnun nimissä”. Virittäjä 1, 1-5. Available online at $<\mathrm{http}$ ://www.kotikielenseura.fi/virittaja/hakemistot/jutut/marttila1_2010.pdf $>$. Accessed on 14.03.2012.

Mäger, Mart (1967) Eesti linnunimetused. Tallinn: Eesti NSV Teaduste Akadeemia.

Mäger, Mart (1969) Linnud rahva keeles ja meeles. Tallinn: Eesti raamat. 
Safina, Èl'vira Irfatovna (2006) Nazvanija ptic v tatarskom jazyke i ix leksikografirovanie. Kazan': Dom pečati.

Sivula, Jaakko (1989) Lintu soidessa sokea: Suomen murteiden kiimatermistö. Helsinki: Suomalaisen Kirjalisuuden Seura.

Sokolov, Serafim Vasil'evič (1973) Nazvanija ptic v udmurtskom jazyke. Tartu.

Svensson, Lars (2009) Collins bird guide. Text and maps by Lars Svensson; illustrations \& captions by Killian Mullarney and Dan Zetterström; with a significant contribution by Peter J. Grant; translated by David Christie and Lars Svensson. London: Collins

Var'ina, V. G. (1976) "Leksičeskaja semantika i vnutrennjaja forma jazykovyx edinic". In Principy $i$ metody semantičeskix issledovanij, 233244. Moskva: Nauka.

Vasil'jev, Valentin Nikolaevič (1982) "Marijskie ornitonimy, ix struktura i istoričeskoe razvitie".In Voprosy marijskoj onomastiki 3, 65-80. Joškar-Ola: Mar. nauč.-issled. institut.

Vasil'jev, Valentin Nikolaevič (1983) "K ètimologii nekotoryx marijskix ornitonimov”. In Voprosy marijskoj onomastiki 4, 32-56. Joškar-Ola: Mar. nauč.-issled. in-t.

Vasil'jev, Valerian Mixajlovič (Üpymarij) (1926) Marij muter. Türlö vere ilyše marijyn mutšym tayastaren nergelyme knaga. Mosko: SSSR kalyk-vlak Rüdö Savyktyš.

\begin{abstract}
Kokkuvõte. Kristina Yuzieva: Linnunimede semantikast mari keeles. Käesolevas artiklis on käsitletud linnunimede semantika iseärasusi mari keeles. On analüüsitud lindudele või nende eluviisile omaseid jooni ja faktoreid, mis on kajastatud linnunimede terminoloogias. Materjalina on kasutatud mari päritoluga sõnavara autori poolt kogutud linnunimede korpusest. Tulemused näitavad, et sajandite jooksul kujunenud ornitoloogilisel sõnavaral on mari keeles kindel struktuur. Terminite tähendus seostub lindude välimuse, häle, eluviisi jt. joontega (või nähtustega). Paljud terminitest edastavad välimusega seostuvaid jooni. Lindude hääled kajastuvad enamasti sel juhul, kui linnud on mingil põhjusel nähtamatud. Mõningate terminite semantikas võib täheldada mitme erineva tunnuse esinemist. Analüüsi tulemustest on näha, et murretes leidub erinevaid nimetusi samade lindude kohta.
\end{abstract}

Märksõnad: linnunimed, ornitonüüm, semantika, motivatsioon, mari keel 